Terbit online pada laman web jurnal : http://e-journal.sastra-unes.com/index.php/JIPS

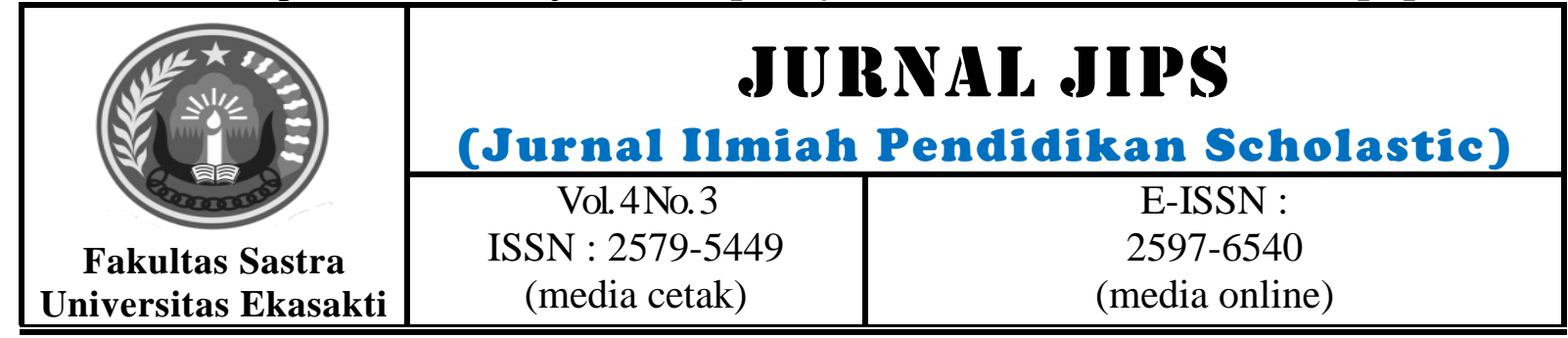

\title{
UPAYA MENINGKATKAN HASIL BELAJAR SISWA KELAS VI PADA SUBTEMA RUKUN DALAM PERBEDAAN DENGAN MENGGUNAKAN METODE PROBLEM BASED LEARNING DI SDN 09 TIMPEH TAHUN PELAJARAN 2020/2021
}

\author{
Suratin
}

SDN 09 Timpeh

\begin{abstract}
Penggunaan metode problem based learning diharapkan dapat meningkatkan aktivitas siswa dalam proses belajar mengajar sehingga dalam proses belajar mengajar itu aktivitas belajar mengajar tidak terjadi kejenuhn, dengan demikian siswa akan terlibat secara fisik, emosional dan intelektual yang pada gilirannya diharapkan konsep perubahan benda yang diajarkan oleh guru dapat dipahami oleh siswa. Permasalahan yang ingin dikaji dalam penelitian ini adalah: (a) Bagaimanakah peningkatan Hasil Belajar belajar sisiwa kelas VI dengan diterapkannya metode problem based learning? (b) Bagaimanakah pengaruh metode demostrasi terhadap motivasi belajar siswa?. Sedangkan tujuan dari penelitian ini adalah: (a) Ingin mengetahui peningkatan Hasil Belajar belajar siswa setelah diterapkannya metode problem based learning. (b) Ingin mengetahui pengaruh motivasi belajar siswa setelah diterapkan metode problem based learning. Penelitian ini menggunakan penelitian tindakan (action research) sebanyak tiga putaran. Setiap putaran terdiri dari empat tahap yaitu: rancangan, kegiatan dan pengamatan, refleksi, dan refisi. Sasaran penelitian ini adalah siswa Kelas VI SDN 09 Timpeh. Data yang diperoleh berupa hasil tes formatif, lembar observasi kegiatan belajar mengajar. Dari hasil analisis didapatkan bahwa Hasil Belajar belajar siswa mengalami peningkatan dari siklus I sampai siklus II yaitu, siklus I (40\%), siklus II (75\%), siklus II (100\%). Kesimpulan dari penelitian ini adalah pembelajaran dengan metode problem based learning dapat berpengaruh positif terhadap Hasil Belajar Siswa kelas VI, serta model pembelajaran ini dapat digunakan sebagai salah satu alternatif pembelajaran pada subtema rukun dalam perbedaan.
\end{abstract}

Keyword: Hasil Belajar, Problem Based Learning

(C) 2020Jurnal JIPS

\section{INTRODUCTION}

Prestasi belajar seorang siswa sebenarnya bukan hanya sekedar angka-angka yang didapat dalam ujian atau merah birunya sebuah rapor. Prestasi belajar siswa sebenarnya adalah ketika siswa telah dapat memahami pengetahuan, serta dapat mempraktikkan ilmunya, siswa berubah perilakunya, akhlaknya, serta membuka pola pikir siswa bahwa ilmu yang mereka dapatkan memiliki kebermaknaan untuk hidup. Oleh karena itu, pendidikan hendaknya mampu 
mendorong kecerdasan dan potensi yang ada pada diri setiap siswa seoptimal mungkin, bukan hanya potensi kecerdasan kognitif atau pengetahuan saja, tetapi harus selalu dibarengi dengan potensi afektif yaitu kemampuan siswa dalam bersikap, serta potensi psikomotorik yaitu potensi keterampilan yang dimiliki siswa.

Pendidikan adalah usaha sadar dan terencana untuk mewujudkan suasana belajar dan proses pembelajaran agar peserta didik secara aktif mengembangkan potensi dirinya untuk memiliki kekuatan spritual keagamaan, pengendalian diri, kepribadian, kecerdasan, akhlak mulia, serta keterampilan yang diperlukan dirinya, masyarakat, bangsa dan negara.

Pendidikan berkualitas dapat terlaksana dengan baik apabila komponen- komponen dalam pendidikan dapat berjalan dengan baik. Salah satu komponen pendidikan yang mutlak ada dan menjadi acuan dalam dunia pendidikan adalah kurikulum. Pengertian kurikulum menurut Sukmadinata (2014, hlm. 5) yaitu, "Kurikulum (curriculum) merupakan suatu rencana yang memberi pedoman atau pegangan dalam proses kegiatan belajar dan mengajar". Jadi, kurikulum diartikan sebagai rencana pendidikan yang memberikan pedoman dan pegangan tentang jenis, lingkup, dan urutan isi serta proses suatu pendidikan. Kurikulum yang baik adalah kurikulum yang dapat mengembangkan seluruh aspek potensi anak secara holistik. Artinya, proses pendidikan dengan menggunakan kurikulum tersebut harus mampu membentuk manusia utuh yang cakap dalam menghadapi dunia yang penuh tantangan dan begitu cepat berubah-ubah, serta mempunyai kesadaran spiritual bahwa dia adalah bagian dari keseluruhan. Oleh karena itu, kurikulum dikatakan baik jika kurikulum tersebut dapat mengembangkan potensi yang ada pada diri siswa, potensi tersebut meliputi aspek fisik, emosi, sosial, kreativitas, spiritual, dan akademik.

Selain kurikulum, semua perangkat di dalam pendidikan harus bersama-sama mengevaluasi diri secara total untuk menuju pembaharuan dan perbaikan yang lebih baik. Teknologi kini berkembang begitu pesat seperti bulldozer raksasa yang siap menggilas bangunan dan penghuninya yang tak mau maju atau bergeser ke arah yang lebih baik. Barang siapa yang tidak mau mengikuti perkembangan zaman, maka ia akan tergilas oleh zaman. Seorang guru harus bisa mengikuti atau bahkan melebihi zaman dengan berbagai inovasi yang baru, "Guru kencing berdiri murid kencing berlari" pepatah ini sungguh menggelitik para tenaga pendidik. Selain harus mengikuti perkembangan zaman, guru juga harus menjadi teladan bagi siswa, karena guru adalah cerminan dari akhlak siswanya.

Tahun 2018 pendidikan Indonesia telah menggunakan Kurikulum 2013 atau biasa disebut juga kurikulum Tematik. "Kurikulum 2013 dikembangkan dengan landasan filosofis yang memberikan dasar bagi pengembangan seluruh potensi peserta didik menjadi manusia Indonesia berkualitas yang tercantum dalam tujuan pendidikan Nasional" (Murfiah, 2017, hlm. 29). Kurikulum 2013 bertujuan agar para siswanya dapat mengembangkan potensi yang ada pada dirinya, siswa dapat berpikir secara kreatif bagi penyelesaian masalah sosial di masyarakat, serta dapat menjadi masyarakat yang demokratis, terampil, dan memiliki akhlak yang mulia. Kurikulum ini adalah berbasis kompetensi yang dirancang untuk memberikan pengalaman belajar seluas-luasnya kepada siswa, agar siswa dapat unggul dalam pengetahuannya, sikap, serta keterampilannya.

Kurikulum 2013 di Sekolah Dasar kini telah menggunakan tema dari setiap pembelajarannya, salah satu tema yang menarik untuk diteliti oleh penulis adalah tema 2 yaitu Persatuan dalam perbedaan dengan subtema Rukun dalam perbedaan. Subtema tersebut berhubungan dengan makna proklamasi kemerdekaan dalam kehidupan sehari-hari. Oleh sebab itu, penting untuk mengajarkan kepada siswa tentang bagaimana manusia seharusnya mempertahankankan kelangsungan hidup tumbuhan, agar tumbuhan dapat hidup terus berdampingan dengan manusia. Selain itu, subtema ini membahas tentang perkembangan tumbuhan dan habitatnya, siswa mampu menyebutkan cir-ciri tumbuhan. Setelah tujuan materi tercapai, siswa tidak hanya memperoleh pengetahuan, tapi siswa juga dapat menggambarkan pengetahuan tersebut, pada akhirnya siswa akan mempraktikkan pengetahuan yang dipelajarinya di kehidupan sehari-hari.

Sayangnya, antara harapan serta tujuan yang diinginkan berbanding terbalik dengan 
kenyataan yang ada di lapangan, dalam praktiknya di sekolah, khususnya sekolah dasar, pembelajaran masih memiliki berbagai macam permasalahan yang perlu diperhatikan, salah satunya adalah permasalahan yang ada di SD Negeri 09 Timpeh. Masalah tersebut diantaranya yaitu hasil belajar yang didapat siswa masih tergolong rendah, nilai kriteria ketuntasan mengajar (KKM) yang mereka dapatkan belum semuanya tuntas. Berdasarkan hasil wawancara penulis dengan guru kelas, hasil belajar kelas VI semester 1 pada Tema 2 subtema rukun dalam perbedaan, menunjukan bahwa dari 20 siswa, hanya $40 \%$ saja yang lulus atau sekitar 8 orang. KKM yang ditentukan adalah sebesar 75 dengan nilai rata-rata kelas tidak mencapai 70 . Selain itu, aktivitas belajar siswa di dalam kelas masih terlihat kurang, pembelajaran di kelas kurang bervariasi sehingga terlihat monoton dan menjenuhkan, guru kelas VI di SD Negeri 09 Timpeh mengatakan bahwa beliau kurang menyukai pembelajaran yang bersifat diskusi, karena pembelajaran diskusi menyebabkan siswa banyak mengobrol, ketika diberi tugas kelompok, maka yang mengerjakan tugas hanya beberapa dari siswa saja, sedangkan siswa yang lain tidak terlihat aktif mengerjakan tugas.

Penyebab timbulnya permasalahan tersebut adalah karena siswa tidak dilatih untuk belajar memecahkan permasalahan, baik yang menyangkut belajarnya maupun hubungan konten ilmu dalam kesehariannya. Materi yang diberikan guru kurang memberikan pancingan kepada siswa untuk dapat memecahkan masalah dalam kehidupan sehari-harinya, sehingga menyebabkan pembelajaran di kelas kurang bermakna bagi siswa. Guru hanya menggunakan metode konvensional, yaitu metode ceramah dan penugasan, pembelajaran di kelas kurang memberikan kesempatan kepada siswa untuk berdiskusi dan mengkomunikasikan pendapat siswa di depan kelas. Guru kurang memberikan ruang kepada siswa untuk berargumentasi dan berimajinasi sesuai dengan ide dan pemikiran siswa. Selain itu, guru hanya menjadi satusatunya sumber pembelajaran siswa, informasi yang siswa dapatkan hanya berdasarkan pengetahuan dari gurunya saja. Guru belum memberikan model dan metode belajar yang variatif untuk dapat memotivasi siswa dalam belajar.
Guru modern zaman sekarang dituntut untuk selalu bisa berinovasi terhadap segala macam pembaharuan, guru harus terus mempelajari penemuan-penemuan baru, melek teknologi, dan perkembangan zaman. Perlu adanya perubahan cara mengajar guru dari model pembelajaran tradisional ke pembelajaran yang modern. Oleh sebab itu, penulis dengan yakin untuk menggunakan model Problem Based Learning untuk memberikan solusi terhadap masalah-masalah yang ada di SD Negeri 09 Timpeh. Penulis memilih model ini karena Problem Based Learning diyakini memiliki keunggulan-keunggulan untuk dapat meningkatkan kemampuan berpikir kreatif dan hasil belajar siswa.

Strategi khusus pada model Problem Based Learning yaitu lebih menekankan siswa pada permasalahan dan tugas-tugas yang akan siswa hadapi, sekaligus usahanya dalam memecahkan serta memberikan solusi kreatifnya terhadap masalah yang dihadapi, sehingga dengan menggunakan model ini siswa akan memecahkan permasalahan dalam kehidupan sehari-harinya dengan pemikiran-pemikirannya yang kreatif.

Berdasarkan hasil observasi, pembelajaran di kelas cenderung berpusat pada guru, sehingga ada beberapa siswa yang belum lulus nilai kriteria ketuntasan minimalnya (KKM). Peneliti kemudian menggunakan model interaktif Problem Based Learning untuk memberikan solusi terhadap permasalahan tersebut. Peneliti ini menggunakan 3 siklus dengan jumlah siswa sebanyak 20 orang. Tahapan penelitian dimulai dengan tahap perencanaan, pelaksanaan, observasi, analisis dan refleksi. Hasil penelitian yang didapatkan menunjukan bahwa pada prasiklus sebanyak 8 siswa memperoleh nilai KKM dengan presentase ketuntasan sebesar $40 \%$, pada siklus I sebanyak 16 siswa mendapat nilai KKM dengan presentase ketuntasan sebesar $80 \%$ dan akhirnya pada siklus II sebanyak 20siswa sudah mendapatkan nilai KKM dan mengalami presentase ketuntasan sebesar 100\%. Dengan demikian, penerapan model Problem Based Learning dikatakan berhasil meningkatkan hasil belajar siswa.

Berdasarkan pendapat ahli dan penelitian terdahulu, penulis berpendapat bahwa model pembelajaran Problem Based Learning menuntut siswa untuk bisa memecahkan masalah yang ada

Jurnal JIPS (Jurnal Ilmiah Pendidikan Scholastic ) Vol. 4 No. 3 (2020) ISSN : 2579-5449

This work is licensed under a Creative Commons Attribution-NonCommercial 4.0 International License. 
di kehidupan sehari-hari, siswa diberikan suatu masalah, kemudian permasalahan tersebut dicari solusinya oleh siswa, baik secara individu atau kelompok. Model ini tentunya dapat merangsang siswa untuk lebih aktif dan berpikir kreatif pada aktivitas belajarnya di kelas, siswa dapat mencari pengetahuan melalui berbagai sumber seperti internet, koran, maupun wawancara di lingkungan sekolah. Model Problem Based Learning dapat mengembangkan kemampuan siswa untuk hidup di lingkungan masyarakat dengan baik, serta dapat memecahkan permasalahan pribadi maupun sosialnya dalam realita kehidupan yang akan mereka jalani.

\section{RESEARCH METHOD}

\section{Tempat Penelitian}

Tempat yang digunakan untuk penelitian. Tempat yang digunakan untuk penelitian yakni ruang kelas VI SDN 09 Timpeh yang beralamat di Timpeh Kecamatan Timpeh Kabupaten Dharmasraya.

2. Waktu Penelitian
Kegiatan penelitian tindakan kelas dilaksanakan pada tahun pelajaran 2020/2021 yaitu pada kelas VI semester I pada tema 2 persatuan dalam perbedaan subtema 1 rukun dalam perbedaan.

\section{A. Subjek Penelitian}

Subjek dalam penelitian ini adalah siswa kelas VI SDN 09 Timpeh dengan jumlah 20 siswa yang terdiri dari 9 siswa laki-laki dan 11 siswa perempuan. Peneliti mengambil subjek penelitian tersebut dengan pertimbangan bahwa pembelajaran menuliskan makna proklamasi kemerdekaan dalam kehidupan sehari-hari dan mengamati ciri-ciri tumbuhan serta habitatnya.

\section{B. Metode Penelitian}

Metode penelitian merupakan cara ilmiah untuk mendapatkan data-data dengan mewujudkan tujuan tertentu (Sugiyono, 2015, hlm. 2). Banyak metode penelitian yang dapat digunakan untuk memberikan solusi terhadap permasalahan pembelajaran. Metode penelitian yang dipilih peneliti adalah penelitian tindakan kelas (PTK). Menurut pendapat Suhardjono (dalam Iskandar dkk, 2015, hlm. 5) "PTK merupakan penelitian tindakan yang dilakukan dengan memperbaiki mutu praktik pembelajaran di kelas". Penelitian tindakan kelas merupakan penelitian yang dilakukan oleh guru (peneliti) atas dasar permasalahan-permasalahan nyata yang ditemui pada saat pembelajaran di kelas.
Tindakan yang dilakukan guru berupa tindakan alternatif pemecahan masalah yang kemudian diuji coba dan dievaluasi pada proses pembelajaran yang sedang berlangsung.

Selain itu, Hopkins (dalam Arikunto, 2012, hlm. 3) menyatakan bahwa penelitian tindakan kelas adalah suatu bentuk kajian yang bersifat reflektif, yang dilakukan oleh pelaku tindakan yaitu guru untuk meningkatkan kemantapan mengajar dalam melaksanakan tugasnya, serta memperdalam pemahaman terhadap kondisi dalam praktik pembelajaran. PTK mengkaji tentang semua aspek kondisi yang ada di dalam kelas, sehingga dapat menemukan permasalahan yang kemudian masalah tersebut dicari solusinya oleh peneliti. Hasil penelitian tersebut kemudian dibuat laporan sesuai dengan kondisi nyata yang dilakukan oleh guru dalam upaya meningkatkan mutu pembelajaran di dalam kelas. Guru menerapkan metode, strategi, dan model pembelajaran yang disesuaikan dengan kondisi kelas dan karakteristik materi pembelajaran di kelas.

Penelitian direncanakan terdiri dari dua siklus. Setiap siklus terdiri dari dua pertemuan, satu pertemuan pembelajaran dan satu pertemuan untuk tes formatif. Prosedur penelitian yang digunakan dalam penelitian ini dapat dilihat pada gambar di bawah ini:

\section{Perencana}

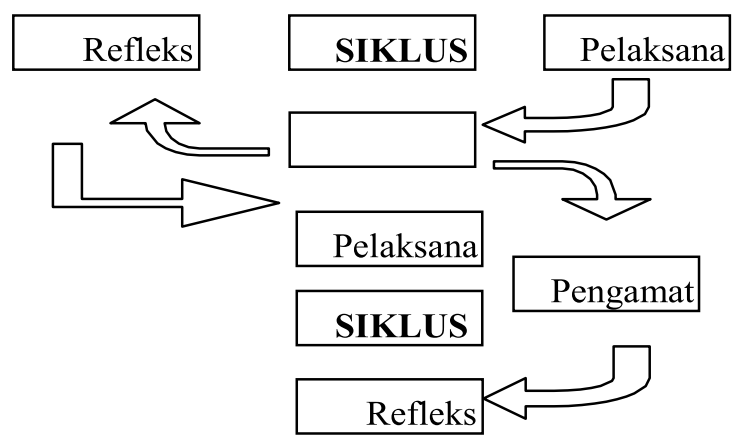

Jurnal JIPS (Jurnal Ilmiah Pendidikan Scholastic ) Vol. 4 No. 3 (2020) ISSN : 2579-5449

This work is licensed under a Creative Commons Attribution-NonCommercial 4.0 International License. 
Gambar 3. 1 Prosedur Penelitian (Arikunto 2009: 16)

Uraian lebih jelas mengenai prosedur penelitian yang akan digunakan peneliti adalah sebagai berikut:

\section{Perencanaan}

Pada tahap ini peneliti menjelaskan tentang apa, mengapa, kapan, di mana, dan bagaimana tindakan itu dilakukan. Kegiatan yang dilakukan dalam perencanaan meliputi: (1) menyusun rencana pelaksanaan pembelajaan, (2) menyusun media pembelajaran, (3) menentukan prosedur penilaian, serta (4) menyusun alat penilian. Perencanaan harus dilakukan dengan seteliti mungkin. Semua kegiatan yang akan dilakukan harus sudah dirancang pada tahap ini. Semakin baik perencanaan yang dilakukan maka diharapkan hasil yang diperoleh juga akan semakin optimal.

\section{Pelaksanaan Tindakan}

Pelaksanaan tindakan merupakan proses penerapan rancangan yang telah dibuat selama proses perencanaan. Kegiatan yang telah dirancang pada tahap perencanaan akan diterapkan dalam tindakan di kelas. Kegiatan yang dilakukan pada tahap ini difokuskan pada penerapan metode Problem Based Learning dalam pembelajaran menirukan dialog drama. Peneliti harus berusaha menerapkan tindakan sesuai yang telah dirumuskan sehingga kegiatan yang telah dilakukan sesuai dengan tujuan semula. Pelaksanaan tindakan harus dilakukan dengan sebaik mungkin agar hasil yang diperoleh menjadi optimal.

\section{$3 . \quad$ Pengamatan}

Selama proses pelaksanaan tindakan berlangsung, peneliti juga bertindak sebagai pengamat. Peneliti mengamati segala sesuatu yang terjadi selama tindakan berlangung. Hal yang perlu diamati dalam tahap ini meliputi hasil, aktivitas belajar siswa, serta performansi guru dalam pelaksanaan pembelajaran. Selama melakukan pengamatan peneliti juga harus mencatat segala sesuatu yang terjadi untuk memperoleh data yang akurat untuk perbaikan siklus berikutnya. Hasil pengamatan nantinya akan direfleksi untuk menentukan kekurangan dan kelebihan selama proses pembelajaran.

\section{Refleksi}

Refleksi dijadikan sebagai bahan evaluasi serta menetapkan kesimpulan yang diperoleh dari penelitian ini. Refleksi merupakan kegiatan untuk mengemukakan kembali apa yang sudah dilakukan. Refleksi digunakan oleh peneliti untuk mengetahui apakah kegiatan yang telah dilakukan sudah berjalan dengan baik atau belum. Refleksi juga dapat digunakan untuk mengetahui kelebihan dan kekurangan dalam proses pembelajaran di kelas selama penelitian berlangsung.

Penulis menyimpulkan bahwa PTK merupakan penelitian yang berawal dari suatu permasalahan yang mucul dalam pembelajaran di kelas, kemudian masalah tersebut dicari solusinya oleh peneliti dengan melakukan tindakan-tindakan berdasarkan permasalahannya. Penelitian tindakan kelas yang dilakukan peneliti bertujuan untuk meningkatkan kualitas sikap dan pengetahuan, khususnya pada kemampuan berpikir kreatif dan hasil belajar siswa.

\section{Teknik Pengumpulan Data}

Menurut Sugiyono (2015, hlm. 224) "teknik pengumpulan data merupakan langkah yang paling strategis dalam penelitian, karena tujuan utama dari penelitian adalah mendapatkan data". Jadi, teknik pengumpulan data adalah langkah-langkah yang diambil peneliti guna memperoleh data penting dalam melakukan penelitian. Pengumpulan data dalam penelitian ini dilakukan pada setiap aktivitas yang berkaitan dengan kegiatan pembelajaran. Rancangan pengumpulan data yang dilakukan di SDN 09 Timpeh yaitu:

\section{Tes}

Tes merupakan salah satu alat untuk melakukan pengukuran, yaitu untuk mengumpulkan karakteristik suatu objek, dalam pembelajaran objek yang dimaksud berupa kecakapan peserta didik, minat, motivasi, dan lain-lain (Widoyoko, 2009, hlm. 44). Dengan menggunakan tes, guru dapat mengetahui sejauhmana siswa dapat memahami materi yang telah diajarkan, guru juga dapat mengetahui keberhasilan model pembelajaran yang telah diajarkan.

Peneliti menggunakan tes berupa pre-test dan post-test. Soal pre-test digunakan untuk mengukur sejauhmana pemahaman atau pengetahuan awal siswa terhadap materi yang akan diajarkan. Soal pre-tes diberikan oleh peneliti sebelum memulai inti kegiatan pembelajaran. Selain itu, soal post-test diberikan 
peneliti setelah siswa selesai belajar dengan menggunakan model Problem Based Learning. Tes yang dilakukan guru tersebut berupa tes pilihan ganda sebanyak 10 soal dan esai sebanyak 5 soal.

\section{Non Tes}

Selain menggunakan tes, peneliti juga menggunakan pengumpulan data secara non tes. Adapun data non tes yang dikumpulkan peneliti adalah sebagai berikut:

\section{Observasi Dokumen Guru}

Dokumen guru adalah perangkat mengajar yang harus disiapkan guru sebelum melakukan pembelajaran di kelas. Dokumen tersebut berupa silabus dan rencana pelaksanaan pembelajaran (RPP). Silabus adalah rancangan pembelajaran yang berisi rencana bahan ajar mata pelajaran tertentu pada jenjang kelas tertentu (Majid, 2011, hlm. 38). Silabus merupakan rangkuman atau ringkasan pokok-pokok intisari kegiatan pembelajaran yang akan dilaksanakan. Selain silabus, dokumen guru yang lain adalah RPP. Rencana pelaksanaan pembelajaran (RPP) merupakan suatu pedoman bagi guru untuk menyiapkan, menyelenggarakan, dan mengevaluasi hasil kegiatan belajar dan pembelajaran (Gintings, 2014, hlm. 224). Jadi, RPP merupakan rincian dari silabus yang telah dibuat oleh peneliti. RPP berisikan indikator, tujuan, materi dan bahan ajar, sumber dan media, serta proses, kegiatan, dan hasil pembelajaran.

\section{Observasi Aktivitas Guru}

Aktivitas guru di dalam kelas harus menciptakan suasana yang kondusif dan membuat pembelajaran menjadi efektif dan menyenangkan (Shoimin, 2014, hlm. 18). Oleh sebab itu, guru harus melakukan aktvitas pembelajaran yang dapat memotivasi siswa untuk belajar dengan sungguh-sungguh. Dalam penelitian ini, aktivitas guru di dalam kelas dinilai dengan menggunakan lembar observasi. Pada lembar ini, guru kelas atau observer menilai aktivitas guru dalam mempraktikkan model Problem Based Learning. Lembar ini juga menilai apakah langkah-langkah yang ada di rencana pelaksanaan pembelajaran (RPP) sesuai dengan yang dilakukan guru pada praktiknya di dalam kelas.

\section{Observasi Kemampuan Berpikir} Kreatif Siswa
Berpikir kreatif berarti berusaha untuk menyelesaikan suatu permasalahan dengan melibatkan segala yang nampak dan fakta serta pengolahan data di dalam otak (Hamzah, dkk, 2011, hlm. 164). Berpikir kreatif membuat siswa aktif untuk memecahkan permasalahan dengan ide-ide yang ada dipikirannya. Fokus ranah sikap yang dinilai dalam penelitian ini adalah sikap kemampuan berpikir kreatif. Sikap ini akan diobservasi ketika siswa melakukan aktivitas pembelajaran menggunakan model Problem Based Learning di kelas. Peneliti akan mengamati perilaku siswa dan keterampilan siswa dalam mengemukakan ide kreatifnya pada saat pembelajaran berlangsung.

4. Angket Respon Siswa

Angket atau kuisioner merupakan teknik pengumpulan data yang dilakukan seseorang dengan memberi seperangkat pertanyaan atau pernyataan tertulis kepada responden untuk dijawab (Sugiyono, 2015, hlm. 142). Angket dalam penelitian ini digunakan untuk memperoleh respon atau tingkat kesukaan siswa terhadap pembelajaran menggunakan model PBL yang dilaksanakan. Siswa diminta untuk menceklis tanggapan dan perasaan siswa selama mengikuti kegiatan pembelajaran menggunakan model Problem Based Learning.

\section{Instrumen Penelitian}

Instrumen digunakan untuk memperoleh data yang akurat dari suatu penelitian. Instrumen penelitian yang digunakan peneliti untuk mengumpulkan data yaitu sebagai berikut:

1. Instrumen Tes

Instrumen tes digunakan untuk mengetahui tingkat keberhasilan belajar siswa sebelum dan setelah mengikuti pembelajaran. Instrumen tes yang digunakan peneliti adalah pretest dan posttest. Soal tersebut berupa soal pilihan ganda sebanyak 5 soal dan esai sebanyak 1 soal. Soal pilihan ganda terdiri dari 1 soal berkategori mudah, 3 soal berkategori sedang, dan 1 soal berkategori sulit. Peneliti memilih soal pilihan ganda karena jenis soal ini dapat digunakan untuk mengukur berbagai jenjang kognitif siswa. Penskoran pilihan ganda termasuk mudah, objektif, cepat, dan dapat mencakup ruang lingkup bahan atau materi pelajaran yang luas.

Selain itu, soal esai yang diberikan peneliti sebanyak 1 buah. Guru memilih soal esai karena soal jenis ini mendorong siswa untuk berpikir dan mengemukakan ide-ide yang kreatif. Guru

Jurnal JIPS (Jurnal Ilmiah Pendidikan Scholastic ) Vol. 4 No. 3 (2020) ISSN : 2579-5449

This work is licensed under a Creative Commons Attribution-NonCommercial 4.0 International License. 
akan menemukan jawaban beragam dari siswa di kelasnya. Tes ini juga dapat meminimalisir terjadinya saling mencontek antar siswa, karena hasil jawaban yang berbeda-beda. Hasil pengembangan soal pretest dan posttest sebagaimana terdapat pada lampiran 2 memuat kisi-kisi

2. Instrumen Non Tes

Instrumen non tes yang dilakukan yaitu dengan cara observasi, dan dokumentasi, intrumen tersebut dapat dikembangkan sebagai berikut:

\section{a. Dokumen Guru (Perangkat} Pembelajaran)

Dokumen guru berupa silabus dan RPP yang dijadikan pedoman guru sebagai peneliti untuk melaksanakan kegiatan pembelajaran. Aspek yang dinilai dari observasi ini adalah sebanyak 6 poin. Aspek tersebut menekankan ketepatan dalam menyajikan unsur-unsur penting dalam RPP yaitu: 1) indikator dan tujuan pembelajaran, 2) materi ajar, 3) penetapan sumber dan media 3) kegiatan pembelajaran, 4) proses pembelajaran, dan 5) hasil belajar.

a. Observasi Guru

Lembar observasi aktivitas guru yang dinilai meliputi kegiatan pendahuluan, kegiatan inti, dan kegiatan penutup. Aspek yang dinilai sebanyak 15 poin, dengan masing-masing diberi rentang nilai $1-5$. Nilai 5 kategori sangat sesuai, nilai 4 kategori sesuai, nilai 3 kategori cukup sesuai, nilai 2 kurang sesuai, dan nilai 1 kategori tidak sesuai. Hasil yang didapat kemudian dibagi dengan skor maksimal dan dikalikan 4 .

\section{E. Teknik Analisis Data}

Teknik analisis data diarahkan untuk menjawab rumusan masalah atau menguji hipotesis yang telah dirumuskan dalam penulisan skripsi. Dalam analisis data, peneliti mencari dan menyusun secara sistematis hasil pengumpulan data dari hasil tes, observasi, dan angket. Teknik analisis data yang digunakan adalah sebagai berikut:

\section{Analisis Data Pre-test dan Post-test}

Soal pretest dan posttest yang diberikan guru berjumlah sebanyak 10 soal pilihan ganda dan 5 soal esai. Setiap soal pilihan ganda yang dijawab benar mendapat nilai 5 poin, sedangkan jawaban benar untuk soal esai akan diberi nilai 10 poin. Skor maksimal dari tes tesebut adalah 100 poin.

\section{Rumus Menghitung Nilai Pre-test dan Post-test Siswa}

\section{F. Indikator Keberhasilan}

Indikator keberhasilan merupakan minimal kemampuan yang harus dicapai oleh siswa dalam rangka proses belajarnya di kelas. Indikator keberhasilan ini dapat menjadi perhitungan tingkat keberhasilan penelitian tindakan kelas dalam meningkatkan kualitas pembelajaran di kelas. Indikator keberhasilan yang ditetapkan oleh peneliti dibagi menjadi 2, yaitu Indikator keberhasilan proses dan indikator keberhasilan output. Indikator tersebut dijelaskan lebih rinci yaitu sebagai berikut:

$$
\mathrm{N}=\frac{\text { Skor perolehan siswa }}{\text { Skormaksimum }} \times 100
$$

Keterangan :

$\mathrm{N}=$ Nilai

\section{RESULTS AND DISCUSSION}

Peneliti telah melaksanakan penelitian dengan menggunakan metode pembelajaran Project Based Learning untuk meningkatkan hasil belajar siswa pada subtema Rukun dalam perbedaan di kelas VI SDN 09 Timpeh Kabupaten Dharmasraya. Penelitian dilakukan dalam dua siklus. Siklus I dilaksanakan pada tanggal 12 Agustus 2020 dan 13 Agustus 2020.
Siklus II dilaksanakan pada tanggal 16 September 2020 dan 18 September 2020.

\section{A. Hasil Penelitian}

1. Prasiklus

Pada pra siklus yang dilakukan melalui metode tanya jawab diketahui bahwa hasil belajar siswa pada subtema rukun dalam 
perbedaan masih rendah. Hasil pembelajaran pra siklus disajikan dalam tabel 4.1 sebagai berikut.

Tabel 4.1. Hasil Belajar Siswa Pada Pra Siklus

\begin{tabular}{|c|c|c|c|c|}
\hline \multirow{3}{*}{$\mathbf{o}$} & \multirow{3}{*}{ Siswa $^{\text {Nama }}$} & \multicolumn{2}{|c|}{$N$} & Keterang \\
\hline & & ilai & an & \\
\hline & & Siswa & untas $^{T}$ & $\begin{array}{l}\text { elum B } \\
\text { Tuntas }\end{array}$ \\
\hline & $\begin{array}{c}\text { Aditya } \\
\text { Gayuh Santosa }\end{array}$ & 5 & $\sqrt{ }$ & \\
\hline & \begin{tabular}{l}
\multicolumn{1}{c}{ Adzra } \\
Rahadatul \\
Aisy
\end{tabular} & 5 & $\sqrt{ }$ & \\
\hline & $\begin{array}{r}\text { Ahmad } \\
\text { Afan Elfikri }\end{array}$ & 0 & & $\sqrt{ }$ \\
\hline & $\begin{array}{l}\text { Amalia } \\
\text { Luhrinjani }\end{array}$ & 0 & & $\sqrt{ }$ \\
\hline & $\begin{array}{r}\text { Aura } \\
\text { Nur Saputri }\end{array}$ & 0 & & $\sqrt{ }$ \\
\hline & $\begin{array}{l}\quad \text { Daud } \\
\text { Clever } \\
\text { Tanjung }\end{array}$ & 0 & & $\sqrt{ }$ \\
\hline & $\begin{array}{l}\text { Deki } \\
\text { Julianto }\end{array}$ & 0 & & $\sqrt{ }$ \\
\hline & $\begin{array}{l}\text { Destiana } \\
\text { Natalia }\end{array}$ & 5 & & $\sqrt{ }$ \\
\hline & $\begin{array}{l}\text { Dian } \\
\text { Fitriyani }\end{array}$ & 5 & $\sqrt{ }$ & \\
\hline 0 & $\begin{array}{r}\text { Hafna } \\
\text { Ilmi Muhalla }\end{array}$ & 0 & $\sqrt{ }$ & \\
\hline 1 & $\begin{array}{r}\text { Jelviqa } \\
\text { Wiekendira } \\
\end{array}$ & 5 & $\sqrt{ }$ & \\
\hline 2 & \begin{tabular}{lr}
\multicolumn{2}{c}{ Muham } \\
mad & Sanju \\
Ariska & \\
\end{tabular} & 0 & $\sqrt{ }$ & \\
\hline 3 & \begin{tabular}{l}
\multicolumn{1}{c}{ Miya } \\
Dwi \\
Setyaningrum
\end{tabular} & 5 & $\sqrt{ }$ & \\
\hline 4 & $\begin{array}{lc} & \text { Noni } \\
\text { Haji } & \text { Novita } \\
\text { Sari } & \end{array}$ & 5 & & $\sqrt{ }$ \\
\hline 5 & $\begin{array}{l}\text { Rachma } \\
\text { t Ferdiansyah }\end{array}$ & 0 & & $\sqrt{ }$ \\
\hline 6 & $\begin{array}{l}\text { Radit } \\
\text { Revaldo }\end{array}$ & 5 & $\sqrt{ }$ & \\
\hline 7 & $\begin{array}{c}\text { Roy } \\
\text { Mardiansyah }\end{array}$ & 0 & & $\sqrt{ }$ \\
\hline 8 & Septi & 5 & & $\sqrt{ }$ \\
\hline
\end{tabular}

\begin{tabular}{||l|l|r|r|r|}
\hline 9 & Ramadhani & & & \\
\hline 9 & $\begin{array}{l}\text { Septians } \\
\text { yah Putri } \\
\text { Rahmadani }\end{array}$ & 5 & & \\
\hline 0 & $\begin{array}{l}\text { Siti } \\
\text { Syarifatul } \\
\text { Nurul } \\
\text { Khasanah }\end{array}$ & 0 & 7 & $\sqrt{ }$ \\
\hline Total & 450 & 8 & \multicolumn{1}{|c|}{1} \\
\hline Rata-rata & $2,5 \%$ & $0 \%$ & $0 \%$ \\
\hline
\end{tabular}

Pada tabel 4.1 disimpulkan bahwa siswa yang mendapat nilai diatas 75 sebanyak 8 orang, atau $40 \%$ sedangkan nilai kurang dari 75 sebanyak 12 siswa atau $60 \%$ dari jumlah 20 siswa. Untuk mengetahui presentasi rentang nilai maka diadakan analisis yang disajikan pada tabel 4.2 dibawah ini.

Tabel 4.2 Analisis Hasil Pra Siklus

\begin{tabular}{|c|c|c|}
\hline o & Nilai & $\begin{array}{l}\text { Jumlah } \\
\text { Siswa }\end{array}$ \\
\hline & $45-54$ & - \\
\hline & $55-64$ & 2 orang \\
\hline & $65-74$ & 9 orang \\
\hline & $75-84$ & 6 orang \\
\hline & $100^{85-}$ & 3 orang \\
\hline & Total & 20 orang \\
\hline
\end{tabular}

Dari hasil analisis pra siklus yang ditampilkan pada tabel 4.2 diatas, penguasaan materi pembelajaran pra siklus bahwa dari jumlah 20 siswa yang mendapat nilai yang mendapat nilai 55-64 sebanyak 2 orang, nilai 65 74 sebanyak 9 orang, nilai $75-84$ sebanyak 6 orang dan 3 orang mendapat nilai diatas 85 . Dari hasil tabel diatas dapat dinyatakan bahwa hasil belajar pada tahapan prasiklus dinyatakan belum tuntas, dikarenakan bahwa masih banyak siswa yang belum mampu mencapai angka ketuntasan minimal yang telah ditetapkan yaitu nilai 75 .

\section{2. Siklus I}

\section{a. Tahap Perencanaan}

Perencanaan untuk persiapan siklus I ini terdiri dari pembuatan Rencana Pelaksanaan Pembelajaran (RPP), lembar observasi guru, lembar observasi siswa, menyiapkan media, 
menyiapkan soal pre test dan post test siklus I terhadap subtema rukun dalam perbedaan.

b. Tahap Pelaksanaan

Pada siklus I tahap pelaksanaan dilaksanakan pada tanggal 12 Agustus 2020 dengan subtema rukun dalam perbedaan. Sebelum pembelajaran dimulai peneliti memberikan tes awal (pretest), dengan test pilihan ganda 10 soal, dengan tujuan untuk mengetahui kemampuan awal siswa tentang materi yang akan dipelajari, dalam proses pembelajaran guru kembali membuat kelompok, setiap kelompok rata-rata berjumlah 5 orang. Selama proses pembelajaran peneliti di bantu oleh observer selaku rejan sejawat untuk mengamati pada proses pembelajaran yang disajikan oleh peneliti. Di akhir pembelajaran peneliti selaku guru memberikan soal post test untuk mengetahui sejauah mana siswa menyerap materi pembelajaran.

\section{c. Hasil}

Pada siklus I yang dilakukan metode Problem Based Learning dengan observer diperoleh informasi bahwa hasil belajar siswa sudah ada peningkatan. Hasil pembelajaran siklus I disajikan dalam tabel 4.3 sebagai berikut.

Tabel 4.3. Hasil Evaluasi Siklus I

\begin{tabular}{|c|c|c|c|c|}
\hline \multirow[t]{2}{*}{$\mathbf{0}$} & \multirow[t]{2}{*}{$\begin{array}{l}\text { Nama } \\
\text { Siswa }\end{array}$} & \multirow{2}{*}{$\begin{array}{l}\text { ilai }^{\mathbf{N}} \\
\text { Siswa }\end{array}$} & \multicolumn{2}{|c|}{$\begin{array}{l}\text { Keterang } \\
\text { an }\end{array}$} \\
\hline & & & $\begin{array}{r}\mathbf{T} \\
\text { untas }\end{array}$ & $\begin{array}{c}\text { B } \\
\text { elum } \\
\text { Tuntas }\end{array}$ \\
\hline & $\begin{array}{l}\quad \text { Aditya } \\
\text { Gayuh } \\
\text { Santosa }\end{array}$ & $0^{9}$ & $\sqrt{ }$ & \\
\hline & $\begin{array}{l}\text { Adzra } \\
\text { Rahadatul } \\
\text { Aisy }\end{array}$ & 0 & $\sqrt{ }$ & \\
\hline & $\begin{array}{l}\text { Ahmad } \\
\text { Afan Elfikri }\end{array}$ & $5^{7}$ & $\sqrt{ }$ & \\
\hline & $\begin{array}{l}\text { Amalia } \\
\text { Luhrinjani }\end{array}$ & $5^{7}$ & $\sqrt{ }$ & \\
\hline & $\begin{array}{r}\text { Aura } \\
\text { Nur Saputri }\end{array}$ & $0^{8}$ & $\sqrt{ }$ & \\
\hline & $\begin{array}{l}\quad \text { Daud } \\
\text { Clever } \\
\text { Tanjung }\end{array}$ & $5^{6}$ & & $\sqrt{ }$ \\
\hline & $\begin{array}{l}\text { Deki } \\
\text { Julianto }\end{array}$ & $5^{7}$ & $\sqrt{ }$ & \\
\hline & $\begin{array}{l}\text { Destia } \\
\text { na Natalia }\end{array}$ & $0^{7}$ & & $\sqrt{ }$ \\
\hline
\end{tabular}

\begin{tabular}{|c|c|c|c|c|}
\hline & $\begin{array}{l}\text { Dian } \\
\text { Fitriyani }\end{array}$ & $5^{8}$ & $\sqrt{ }$ & \\
\hline 0 & $\begin{array}{c}\text { Hafna } \\
\text { Ilmi Muhalla }\end{array}$ & $5^{8}$ & $\sqrt{ }$ & \\
\hline 1 & $\begin{array}{l}\text { Jelviqa } \\
\text { Wiekendira }\end{array}$ & $5^{9}$ & $\sqrt{ }$ & \\
\hline 2 & \begin{tabular}{l}
\multicolumn{2}{c}{ Muha } \\
mmad Sanju \\
Ariska
\end{tabular} & 0 & $\sqrt{ }$ & \\
\hline 3 & \begin{tabular}{l}
\multicolumn{1}{c}{ Miya } \\
Dwi \\
Setyaningrum
\end{tabular} & $5^{8}$ & $\sqrt{ }$ & \\
\hline 4 & $\begin{array}{ll} & \text { Noni } \\
\text { Haji } & \text { Novita } \\
\text { Sari } & \end{array}$ & $0^{7}$ & & $\sqrt{ }$ \\
\hline 5 & $\begin{array}{l}\text { Rachm } \\
\text { at } \\
\text { Ferdiansyah }\end{array}$ & $5^{7}$ & $\sqrt{ }$ & \\
\hline 6 & $\begin{array}{l}\text { Radit } \\
\text { Revaldo }\end{array}$ & $5^{9}$ & $\sqrt{ }$ & \\
\hline 7 & $\begin{array}{c}\text { Roy } \\
\text { Mardiansyah }\end{array}$ & $0^{8}$ & $\sqrt{ }$ & \\
\hline 8 & $\begin{array}{l}\text { Selvina } \\
\text { Septi } \\
\text { Ramadhani } \\
\end{array}$ & $0^{7}$ & & $\sqrt{ }$ \\
\hline 9 & $\begin{array}{l}\text { Septian } \\
\text { syah Putri } \\
\text { Rahmadani }\end{array}$ & $0^{7}$ & & $\sqrt{ }$ \\
\hline 0 & $\begin{array}{l}\text { Siti } \\
\text { Syarifatul } \\
\text { Nurul } \\
\text { Khasanah } \\
\end{array}$ & $5^{7}$ & $\sqrt{ }$ & \\
\hline & Total & $585^{1}$ & $5^{1}$ & 5 \\
\hline & Rata-rata & $\begin{array}{r}7 \\
9,25 \% \\
\end{array}$ & $5 \%$ & $5 \%^{2}$ \\
\hline
\end{tabular}

Dari tabel 4.3 dapat disimpulkan bahwa siswa yang mendapat nilai diatas 75 sebanyak 15 orang atau $75 \%$ sedangkan nilai kurang dari 75 sebanyak 5 siswa atau $25 \%$ dari 20 siswa. Untuk mengetahui presentasi rentang nilai analisis yang disajikan pada tabel 4.4 dibawah ini.

Tabel 4.4. Analisis Hasil Siklus I

\begin{tabular}{|l|c|c|}
\hline & Nilai & \multicolumn{2}{|c|}{ Jumlah } \\
o & & Siswa \\
\hline & $45-54$ & - \\
\hline & $55-64$ & - orang \\
\hline & $65-74$ & 5 orang \\
\hline
\end{tabular}

Jurnal JIPS (Jurnal Ilmiah Pendidikan Scholastic) Vol. 4 No. 3 (2020) ISSN : 2579-5449 


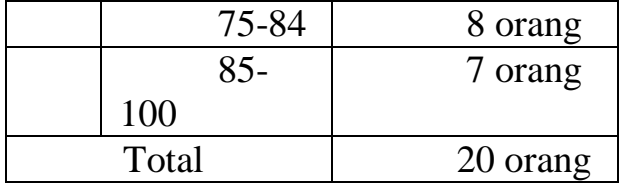

Dari hasil analisis siklus I yang ditampilkan pada tabel 4.4 diatas, penguasaan materi pembelajaran dari jumlah 20 siswa yang mendapat nilai yang mendapat nilai 65 sampai 74 sebanyak 5 orang, nilai 75 sampai 84 sebanyak 8 orang dan nilai 85 sampai dengan 100 sebanyak 7 orang

Kurang berhasilnya pembelajaran pada siklus I dikarenakan siswa yang belum terbiasa dengan penggunaan metode pembelajaran Problem Based Learning. Siswa juga belum dapat bekerjasama dengan teman sekelompoknya. Siswa juga kurang bertanggung jawab dengan tugasnya masing-masing. Selain itu, terdapat beberapa siswa yang kurang memperhatikan penjelasan guru dan lebih asik bermain sendiri sehingga menyebabkan hasil belajar siswa menjadi rendah. Pada siklus I ini masih ada 5 siswa yang belum mampu mencapai nilai dari KKM yang di tetapkan, untuk itu peneliti perlu mengadakan siklus II demi mengoptimalkan hasil belajar siswa terhadap subtema rukun dalam perbedaan.

\section{Siklus II}

a. Tahap perencanaan

Tahap perencanaan pada siklus II merupakan perbaikan dari siklus I. perencanaan dimulai dengan menyiapkan silabus, RPP, menyiapkan media, menyiapkan soal pre test dan post test, menyiapkan kelompok setiap masingmasing siswa.

\section{b. Tahap Pelaksanaan}

Pada siklus II dilakukan pada tanggal 16 September dan 18 September 2020. Ssebelum pembelajaran dimulai guru memberikan pre tes, untuk mengetahui pengetahuan awal siswa tentang materi yang akan diajarkan, selama proses pembelajaran peneliti dibantu oleh rekan sejawat selaku observer untuk mengamati aktivitas siswa dan guru. Penilaian pada pertemuan ini dilakukan dalam bentuk penilaian performen untuk melihat peran aktif siswa dalam diskusi.

$$
\text { c. Hasil }
$$

Pada siklus II diperoleh informasi bahwa semua siswa sudah mampu memahami pada pembelajaran, hal tersebut diketahui bahwa seluruh siswa sudah mampu memperoleh nilai diatas KKM yang ditentukan. Hasil pembelajaran siklus II disajikan dalam tabel 4.5 sebagai berikut.

Tabel 4.5. Hasil Evaluasi Siklus II

\begin{tabular}{|c|c|c|c|c|}
\hline \multirow[t]{2}{*}{$\mathbf{0}$} & \multirow[t]{2}{*}{$\begin{array}{l}\text { Nama } \\
\text { Siswa }\end{array}$} & \multirow{2}{*}{$\begin{array}{c}\text { ilai } \\
\text { Siswa }\end{array}$} & \multicolumn{2}{|c|}{$\begin{array}{l}\text { Keterang } \\
\text { an }\end{array}$} \\
\hline & & & ${ }_{\text {untas }}^{\text {T }}$ & \begin{tabular}{|l} 
B \\
elum \\
Tuntas
\end{tabular} \\
\hline & $\begin{array}{c}\text { Aditya } \\
\text { Gayuh Santosa }\end{array}$ & $00^{1}$ & $\sqrt{ }$ & \\
\hline & $\begin{array}{l}\text { Adzra } \\
\text { Rahadatul } \\
\text { Aisy }\end{array}$ & 8 & $\sqrt{ }$ & \\
\hline & $\begin{array}{r}\text { Ahmad } \\
\text { Afan Elfikri }\end{array}$ & 8 & $\sqrt{ }$ & \\
\hline & $\begin{array}{l}\text { Amalia } \\
\text { Luhrinjani }\end{array}$ & 8 & $\sqrt{ }$ & \\
\hline & $\begin{array}{r}\text { Aura } \\
\text { Nur Saputri }\end{array}$ & 0 & $\sqrt{ }$ & \\
\hline & $\begin{array}{l}\quad \text { Daud } \\
\text { Clever } \\
\text { Tanjung }\end{array}$ & 5 & $\sqrt{ }$ & \\
\hline & $\begin{array}{l}\text { Deki } \\
\text { Julianto }\end{array}$ & 8 & $\sqrt{ }$ & \\
\hline & $\begin{array}{l}\text { Destiana } \\
\text { Natalia }\end{array}$ & 8 & $\sqrt{ }$ & \\
\hline & $\begin{array}{l}\text { Dian } \\
\text { Fitriyani }\end{array}$ & 9 & $\sqrt{ }$ & \\
\hline 0 & $\begin{array}{r}\text { Hafna } \\
\text { Ilmi Muhalla }\end{array}$ & 9 & $\sqrt{ }$ & \\
\hline 1 & $\begin{array}{r}\text { Jelviqa } \\
\text { Wiekendira }\end{array}$ & 00 & $\sqrt{ }$ & \\
\hline 2 & $\begin{array}{lr} & \text { Muham } \\
\text { mad } & \text { Sanju } \\
\text { Ariska } & \\
\end{array}$ & 00 & $\sqrt{ }$ & \\
\hline 3 & \begin{tabular}{l}
\multicolumn{1}{c}{ Miya } \\
Dwi \\
Setyaningrum
\end{tabular} & 9 & $\sqrt{ }$ & \\
\hline 4 & $\begin{array}{lc} & \text { Noni } \\
\text { Haji } & \text { Novita } \\
\text { Sari } & \\
\end{array}$ & 0 & $\sqrt{ }$ & \\
\hline 5 & $\begin{array}{l}\text { Rachma } \\
\text { t Ferdiansyah }\end{array}$ & 8 & $\sqrt{ }$ & \\
\hline 6 & $\begin{array}{l}\text { Radit } \\
\text { Revaldo }\end{array}$ & $00^{1}$ & $\sqrt{ }$ & \\
\hline
\end{tabular}

Jurnal JIPS (Jurnal Ilmiah Pendidikan Scholastic ) Vol. 4 No. 3 (2020) ISSN : 2579-5449

This work is licensed under a Creative Commons Attribution-NonCommercial 4.0 International License. 


\begin{tabular}{|c|c|c|c|c|}
\hline 7 & $\begin{array}{c}\text { Roy } \\
\text { Mardiansyah } \\
\end{array}$ & 0 & $\sqrt{ }$ & \\
\hline 8 & $\begin{array}{l}\text { Selvina } \\
\text { Septi } \\
\text { Ramadhani }\end{array}$ & 5 & $\sqrt{ }$ & \\
\hline 9 & $\begin{array}{lr}\text { Septians } \\
\text { yah } & \text { Putri } \\
\text { Rahmadani }\end{array}$ & 5 & $\sqrt{ }$ & \\
\hline 0 & \begin{tabular}{l}
\multicolumn{1}{r}{ Siti } \\
Syarifatul \\
Nurul \\
Khasanah
\end{tabular} & 0 & $\sqrt{ }$ & \\
\hline & Total & $750^{1}$ & $0^{2}$ & \\
\hline & Rata-rata & $7,5 \%$ & $00 \%{ }^{1}$ & \\
\hline
\end{tabular}

Hasil belajar siswa mengalami peningkatan pada pelaksanaan siklus II. Pada pelaksanaan tes pada pembelajaran siklus II diperoleh nilai rata-rata sebesar 87,5 dengan persentase ketuntasan belajar klasikal sebesar $100 \%$. Peningkatan ini terjadi karena pada pelaksanaan pembelajaran siklus II siswa sudah mulai terbiasa dengan penggunaan metode Problem Based Learning dalam pembelajaran. Siswa juga sudah mulai dapat bekerjasama dan bertanggung jawab dengan tugasnya masingmasing. Siswa juga sudah tidak malu untuk mengungkapkan pendapatnya di depan kelas. Untuk mengetahui presentasi rentang nilai maka diadakan analisis yang disajikan pada tabel 4.6 dibawah ini.

Tabel 4.6. Analisis Hasil Siklus II

\begin{tabular}{|c|c|c|}
\hline $\mathrm{o}$ & Nilai & $\begin{array}{l}\text { Jumlah } \\
\text { Siswa }\end{array}$ \\
\hline & $45-54$ & - \\
\hline & $55-64$ & - orang \\
\hline & $65-74$ & - orang \\
\hline & $75-84$ & 7 orang \\
\hline & $100^{85-}$ & 13 orang \\
\hline & Total & 20 orang \\
\hline
\end{tabular}

Dari hasil analisis siklus II yang ditampilkan pada tabel 4.6 diatas, penguasaan materi pembelajaran bahwa dari jumlah 20 siswa yang mendapat nilai yang mendapat nilai 75 sampai 84 sebanyak 7 orang, nilai 85 sampai 100 sebanyak 13 orang.
Berdasarkan data hasil belajar siswa diketahui bahwa terjadi peningkatan hasil belajar siswa. Berikut peningkatan hasil belajar siswa disajikan dalam tabel dan grafik.

Grafik 4.1 Peningkatan Hasil Belajar Siswa

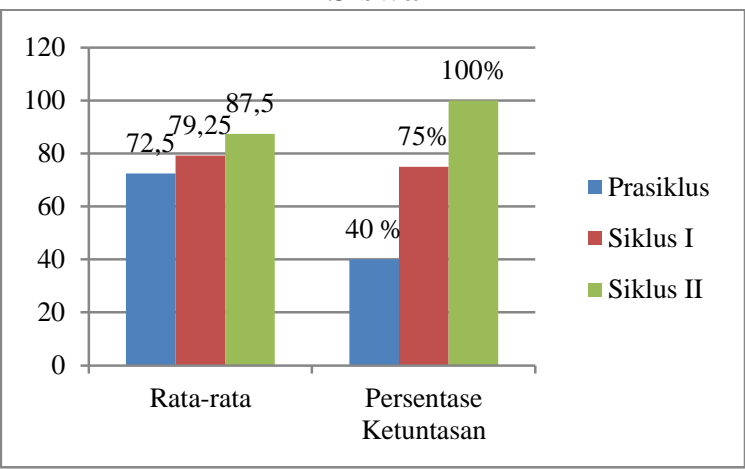

Berdasarkan tabel 4.7 dan grafik 4.1 dapat diketahui bahwa rata-rata nilai yang diperoleh siswa pada prasiklus yakni 72,5. Rata-rata nilai yang diperoleh pada siklus I yakni 79,25. Pada siklus II meningkat menjadi 87,5. Hal tersebut menunjukkan adanya peningkatan jumlah nilai dari prasiklus, siklus I dan siklus II.

Persentase ketuntasan belajar klasikal siswa juga mengalami peningkatan. Pada prasiklus terdapat 8 dari 20 siswa yang tuntas belajar. Persentase ketuntasan belajar klasikal yang diperoleh pada prasiklus yakni sebesar 40\%. Pada siklus I terdapat 15 dari 20 siwa yang tuntas belajar, untuk presentase ketuntasan belajar yang diperoleh pada siklus I adalah $75 \%$. Pada siklus II terdapat 20 siswa yang tuntas belajar. Persentase ketuntasan belajar klasikal pada siklus II yakni sebesar $100 \%$. Hal tersebut menunjukkan adanya peningkatan persentase ketuntasan belajar klasikal siswa sebesar 35\% dari prasiklus ke siklus I, sedangkan peningkatan ketuntasan belajar dari siklus I ke siklus II sebesar $25 \%$.

Hasil belajar yang diperoleh pada siklus II dianggap memuaskan bagi peneliti. Hal tersebut dikarenakan hasil belajar yang diperoleh siswa telah mencapai kriteria keberhasilan yang telah ditentukan. Berdasarkan hasil tersebut maka, pembelajaran pada siklus II dikatakan berhasil.

Berdasarkan hasil analisis data, diketahui bahwa hasil belajar siswa pada siklus II mengalami peningkatan dari prasiklus dan siklus I. Pada prasiklus diperoleh nilai rata-rata kelas sebesar 72,5 dengan persentase ketuntasan belajar sebesar $40 \%$. Hasil yang diperoleh pada prasiklus belum dapat mencapai kriteria 
keberhasilan yang ditentukan. Hal tersebut dikarenakan tidak adanya penerapan metode yang bervariatif. Pada siklus I diperoleh nilai rata-rata kelas sebesar 79,25 dengan persentase ketuntasan belajar sebesar 75\%. Pada siklus I siswa belum terbiasa dengan penerapan metode Problem Based Learning. Pada siklus II diperoleh nilai rata-rata kelas sebesar 87,5 dengan persentase ketuntasan belajar siswa sebesar $100 \%$. Hal tersebut menunjukkan bahwa penerapan metode Problem Based Learning dapat meningkatkan hasil belajar siswa pada

\section{CONCLUSION}

Merujuk pada hasil penelitian beserta pembahasan yang telah diuraikan dapat disimpulkan bahwa penerapan metode pembelajaran Problem Based Learning dapat meningkatkan hasil subtema rukun dalam perbedaan di kelas VI SDN 09 Timpeh. Berdasarkan hasil penelitian yang telah dilakukan, maka dapat disimpulkan bahwa penerapan metode Problem Based Learning dalam subtema rukun dalam perbedaan dapat meningkatkan hasil belajar siswa.

Pada pembelajaran tersebut terjadi peningkatan hasil belajar siswa dari siklus I ke siklus II. Nilai rata-rata siswa sebelum diterapkannya metode Problem Based Learning adalah 72,14 dengan ketuntasan belajar hanya $38 \%$ atau 8 dari 21 siswa yang mampu mencapi KKM

Pada siklus I menunjukkan terdapat 16 dari 21 siswa yang tuntas belajar. Persentase ketuntasan belajar klasikal pada siklus I sebesar $76 \%$ dengan nilai rata-rata kelas sebesar 79,04. Pada siklus II terjadi peningkatan hasil belajar siswa.

Pada siklus II seluruh siswa mampu mencapai angka KKM yang telah ditetapkan yaitu nilai 75. Persentase ketuntasan belajar subtema rukun dalam perbedaan di kelas VI SDN 09 Timpeh.

Berdasakan uraian di atas diketahui bahwa penerapan metode Problem Based Learning dapat meningkatkan hasil belajar siswa dalam subtema rukun dalam perbedaan siswa kelas VI SDN 09 Timpeh. Dengan demikian kualitas di kelas VI SDN 09 Timpeh menjadi meningkat setelah diterapkan metode Problem Based Learning.

klasikal pada siklus II sebesar $100 \%$ dengan nilai rata-rata kelas 87,38.

\section{A. Saran}

Berdasarkan hasil penelitian yang telah dilakukan, peneliti memberikan saran sebagai berikut:

1. Metode pembelajran Problem Based Learning, dapat dijadikan alternatif metode pembelajaran yang dapat digunakan guru. Berdasarkan hasil penelitian yang telah dilakukan terbukti bahwa model ini dapat meningkatkan hasil belajar siswa. Oleh karena itu guru hendaknya mencoba untuk menerapkan metode pembelajaran Problem Based Learning dalam proses pembelajaran di kelas.

2. Guru hendaknya selalu berusaha melakukan inovasi untuk memilih model pembelajaran yang akan digunakan. Dengan demikian siswa tidak merasa bosan dan menjadi bersemangat ketika mengikuti pembelajaran.

Sekolah hendaknya memberikan kesempatan kepada guru agar dapat berinovasi dan berkreativitas dalam kegiatan pembelajaran. Sebagai contoh, dengan menggunakan metode pembelajaran Problem Based Learning, guru dapat memberikan kontribusi untuk meningkatkan kualitas dan mutu sekolah. 


\section{Bibliography}

[1]Arikunto. 2009. Penelitian Tindakan Kelas. Jakarta: PT. Bumi Aksara. -------- 2012. Penelitian Tindakan Kelas. Jakarta: PT. Bumi Aksara.

[2]Gintings, A. 2014. Belajar dan Pembelajaran. Bandung: Humaniora.

[3]Hamzah, dkk. 2012. Belajar dengan Pendekatan PAILKEM Pembelajaran Aktif, Inovatif, Lingkungan, Kreatif, Efektif, Menarik. Jakarta: PT Bumi Aksara.

[4]Iskandar, dkk. 2015. Penelitian Tindakan Kelas dan publikasinya untuk Kenaikan Pangkat dan Golongan Guru \& Pedoman Penelitian PTK bagi Mahasiswa. Cilacap: Ihya Media.

[5]Majid, A. 2011. Penilaian Auntentik Proses dan Hasil Belajar. Bandung: Remaja Rosdakarya.

[6]Murfiah, U. 2017. Pembelajaran Terpadu. Bandung: Universitas Pasundan.

[7]Putra, S. R. 2013. Desain Belajar Mengajar Kreatif Berbasis Sains. Yogyakarta: DIVA PRESS.
[8]Rusman. 2012. Model Model Pembelajaran. Depok: PT Rajagrafindo Persada.

[9]Rusmono. 2014. Strategi Pembelajaran PBL itu Perlu. Bogor: Ghalia Indonesia.

[10]Shoimin, A. 2014. 68 Model Pembelajaran Inovatif dalam Kurikulum 2013. Yogyakarta: Ar-Ruzz Media.

[11]Sudjana, N. 2010. Penilaian Hasil Proses Belajar Mengajar. Bandung: PT Remaja Rosdakarya.

[12]Sugiyono. 2015. Metode Penelitian Manajemen. Bandung: Alfabeta.

[13]Sukmadinata, N. S. 2014. Pengembangan Kurikulum. Bandung: PT Remaja Rosdakarya.

[14]Toharudin, U. 2011. Membangun Literasi Sains Peserta Didik. Bandung: Humaniora.

[15]Widoyoko, E. P. 2009. Evaluasi Program Pembelajaran Panduan Praktis Bagi Pendidik dan Calon Pendidik. Yogyakarta: Pustaka Pelajar. 